\title{
Potential Inhibition by Phaleria macrocarpa Leaves Ethanol Extract on Ki-67 Expression in Distal Colon Mouse
}

\author{
Kusmardi Kusmardi ${ }^{1 * *}$, Elvan Wiyarta ${ }^{2}$, Ari Estuningtyas ${ }^{3}$, Nurhuda Sahar ${ }^{4}$, Yurnadi Hanafi Midoen ${ }^{4}$, Aryo \\ Tedjo $^{5}$, Alfred Pakpahan 6
}

Kusmardi Kusmardi ${ }^{1}, *$, Elvan Wiyarta², Ari Estuningtyas ${ }^{3}$, Nurhuda Sahar ${ }^{4}$, Yurnadi Hanafi Midoen ${ }^{4}$, Aryo Tedjo ${ }^{5}$, Alfred Pakpahan $^{6}$

'Department of Anatomic Pathology, Drug Development Research Cluster, Human Cancer Research Center, IMERI, Faculty of Medicine, Universitas Indonesia, Jl. Salemba Raya 6 Jakarta, INDONESIA.

${ }^{2}$ Faculty of Medicine, Universitas Indonesia, Jl. Salemba Raya 6 Jakarta, INDONESIA. ${ }^{3}$ Department of Pharmacology and

Therapeutic, Faculty of Medicine, Universitas Indonesia, Jl. Salemba Raya 6 Jakarta, INDONESIA.

${ }^{4}$ Department of Medical Biology, Faculty of Medicine, Universitas Indonesia, Jl. Salemba Raya 6 Jakarta, INDONESIA.

${ }^{5}$ Department of Medical Chemistry, Faculty of Medicine, Universitas Indonesia, Jl. Salemba Raya 6 Jakarta, INDONESIA.

${ }^{6}$ Department of Oral Biology, Faculty of

Dentistry, Universitas Trisakti, Jl. Kyai Tapa Jakarta, INDONESIA.

\section{Correspondence}

\section{Kusmardi Kusmardi}

Department of Anatomic Pathology, Drug Development Research Cluster, Human Cancer Research Center, IMERI, Faculty of Medicine Universitas Indonesia, JI. Salemba Raya 6 Jakarta, INDONESIA.

E-mail: kusmardi.ms@ui.ac.id

History

- Submission Date: 28-10-2020;

- Review completed: 05-12-2020

- Accepted Date: 09-12-2020.

DOI : 10.5530/pj.2021.13.56

Article Available online

http://www.phcogj.com/v13/i2

Copyright

(C) 2021 Phcogj.Com. This is an openaccess article distributed under the terms of the Creative Commons Attribution 4.0 International license.

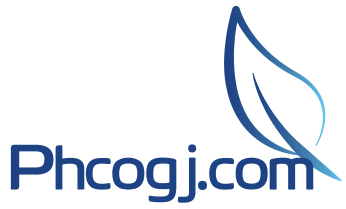

\section{ABSTRACT}

Ulcerative colitis (UC) has been an important aspect of an incurable chronic inflammatory disease over the last few decades. To find useful therapies for UC, one of which is herbal therapy, many researches have been conducted. Due to its anti-inflammatory effects, Phaleria macrocarpa (PM), an Indonesian indigenous herb, is considered to be the alternative therapy for UC. Phaleria macrocarpa Leaves Ethanol Extract (PMLEE) is then used in this research to determine its effect on UC by using Ki-67 as a marker of proliferation. PMLEE was created from dry PM content undergoing maceration. The animals were classified into six categories: normal, positive control, negative control and PMLEE group (100, 200, $300 \mathrm{mg} / \mathrm{kgBW})$. PMLEE was then injected for 7 consecutive days into BALB/c mice that were caused by dextran sodium sulphate (DSS). DSS is used for modeling UC in the colon tissue of mice. All mice were terminated and then stained with anti-Ki-67 after their colons were extracted. Subsequently, the stained parts were analyzed with ImageJ based on the color intensity produced by the results of $\mathrm{H}$-score. Based on $\mathrm{H}$-score, PMLEE $300 \mathrm{mg}$ and $200 \mathrm{mg}$ has significantly decreased the expression of Ki-67 compare to the negative control $(p=0.001$ and $p=0.01)$. PMLEE also has a tendency to be dose dependent based on the significant difference from PMLEE 300mg and $100 \mathrm{mg}(\mathrm{p}=0.002)$. It then concludes that PMLEE is related to Ki-67 expression in cells, as it was inversely proportional in this analysis.

Key words: Mahkota Dewa (Phaleria macrocarpa), Inflamation, Dextran sodium sulphate, Ki67.

\section{INTRODUCTION}

Over the last few years, UC has grown in significance as part of chronic incurable inflammatory diseases. ${ }^{1}$ UC pathogenesis has yet to be seen, but several causes, such as the colon environment, biology, and tissue structure problem which in the end leads to prolonged inflammation are known to be causing them. ${ }^{1}$ The prevalence of UC in South East Asia even reached 6.67/100,000 individuals. ${ }^{2}$ In Indonesia, the UC prevalence has also tripled since $1990 .^{3}$ This chronic condition often demands high treatment costs, apart from having an effect on the quality of life (QoL). ${ }^{4}$ The annual average costs of care with an anti-tumor necrosis factor (TNF), typical medicine for UC, are EUR $15.775 .{ }^{5}$ If not treated, patients suffering from UC may be at risk of colectomy, or may also be at risk of death by causing colorectal cancer. ${ }^{6}$

Many researches have been carried out over the last few years in order to identify successful UC therapies. Aspirin is presently the common UC therapy. ${ }^{7}$ However, this drug has some significant side effects, starting from nausea, vomiting, hepatitis, to male infertility, and can require a variety of clinical approaches for the treatment of UC because of phenotypic variability ${ }^{4,7}$ Other therapies currently under development include plant-based herbal therapeutics. ${ }^{8}$ Herbal therapy has also been researched extensively for the effectiveness, efficacy, and safety. ${ }^{9}$ Mahkota Dewa (Phaleria macrocarpa) is one of Indonesia's most widely-associated tropical plants, of which are considered an alternative antiinflammatory therapy. ${ }^{10}$

To date, PM literature as an anti-inflammatory treatment remains limited. In fact, there is a need for more studies on the pharmacological effects of PM. The authors then carried out an analysis of the PM extract. The extract used is known as the Phaleria macrocarpa Leaves Ethanol Extract (PMLEE). PMLEE is given to the colon tissue of mice, which has UC modeled with Dextran Sodium Sulphate (DSS). DSS is a pro-inflammatory agent generally believed to cause long-lasting inflammation. In addition, the Ki-67 protein was chosen as marker to determine PMLEE relationship with UC. This protein has a role in inflammatory process that can be assessed by immunohistochemistry. ${ }^{11,12}$ Accordingly, the effect of PMLEE on UC could be defined by the measurement of Ki-67 expression. This study can provide insights into PMLEE's anti-inflammatory function and the basis for the development of PM as a possible alternative treatment for UC.

\section{MATERIALS AND METHODS}

\section{Experimental animal}

$\mathrm{BALB} / \mathrm{c}$ mice in the Animal Laboratories, National Institute of Medicine, Research and Development, Ministry of Health, Indonesia have been adapted and 
studied for one week (eating, drinking, movement and body weight) prior to induction of dextran sodium sulphate (DSS). Treatment and conservation of mice in compliance with the Reference to the Care and Usage of Laboratory Animals by the Animal Care and Use Committee, including by controlling temperatures of $25^{\circ} \mathrm{C}, 12$ hours of light/dark period, $55 \%$ humidity, as well as normal food and water.

\section{Chemical material}

Reagents used in this study include dextran sodium sulphate BM 500,000 (Sigma Aldrich), Aspirin (Brataco Inc.), sodium carboxymethylcellulose / CMC Na (Brataco Inc.), anti-Ki-67 (Abcam), formaldehyde (Brataco Inc.), ether (Brataco Inc.), xylol (Merck), absolute alcohol (Merck), 70\% alcohol (Merck), paraffin solidum (Brataco Inc.).

\section{Plant extract preparation}

PM leaves were collected from the Traditional Medicine Crops Research Institute, Ministry of Agriculture in Indonesia. Using purified water, it was washed and then allowed to shade dry. The dried material was homogenized into fine powder and kept at room temperature. The dried material is then macerated using a process adapted from the Wilson method. ${ }^{13}$

The fine dried powder was saturated with 3 Liters of $70 \%$ ethanol solvent. After 24 hours, the extract was filtered using the Whatman filter paper. The residue was further extracted for 24 hours. The extract is then purified and the filtrate is extracted. The filtrate was then thickened using a rotary evaporator until it became a thick extract (16 percent moisture content). The extract obtained by maceration provided phenol with a grade of $4.4103 \%$ or $44.103 \mathrm{GAE} / \mathrm{g}$, flavonoids with a level of $0.3429 \%$ or $3.429 \mathrm{mgQE} / \mathrm{g}$ and an IC50 of $219.716 \mu \mathrm{g} / \mathrm{mL}$ (moderate antioxidant intensity). ${ }^{13}$

\section{Study design and DSS administration}

The experimental protocols have been accepted by the Ethics Committee of the Faculty of Medicine, Universitas Indonesia. Animals were induced with $2 \%$ DSS for 7 consecutive days, except for the normal group. Animals were classified into six categories: normal control, negative control, positive control (aspirin) and PMLEE (100, $200,300 \mathrm{mg} / \mathrm{kg} \mathrm{BW}$ ), with each group consisting of 5 mice. Normal group received $0.9 \%$ saline and did not receive oral exposure to DSS. ${ }^{13}$ Animals were randomized and acclimatized one week prior to the introduction of DSS. After seven consecutive days of DSS induction, the positive control group obtained aspirin solution and the PMLEE group received PMLEE $(100,200,300 \mathrm{mg})$ by oral administration every day for 2 weeks. At the end of the treatment, all the mice were terminated and the colons were collected.

\section{Tissue handling and immunohistochemistry}

In this process, the distal third of colon was washed and fixed using a $10 \%$ formalin solution, embedded in the paraffin medium, sliced transversely using a $4 \mathrm{~mm}$ microtome, and mounted on a slide for further immunohistochemical staining (IHC). The IHC was performed by deparaffinization, rehydration, antigen retrieval, and blocking. The slides were then incubated with anti-Ki-67 antibodies in phosphate buffer solution (PBS) for 2 hours at room temperature, then visualized with $3,3^{\prime}$-diaminobenzidine (DAB) for 10 minutes. ${ }^{13,14}$ The sample sections were dipped in Lilie Mayer haematoxylin solution as counterstain for 2 minutes and then rinsed again with water. ${ }^{15} \mathrm{Next}$, the sections were dipped in lithium carbonate for 60 seconds and then rinsed. Slides were dehydrated using ethanol and xylol clearing. Finally, the pieces were covered by a liquid mask, which is an aqueous mounting medium. Subsequently, the stained slides were analyzed for histopathological change.

\section{Quantification of KI-67 expression}

Each slide was examined using a light microscope with high power field (400x magnification) and filmed using a Leica LAZ EZ software computer and a camera combined with the Leica DM750 microscope. Photographs were taken randomly for a limit of five visual fields per slide. The brown color intensity was then measured using the plugin software in Image J, IHC profiler, which quantifies the color intensity in the image. The quantification results are in the form of the $\mathrm{H}$ score.

\section{Statistical analysis}

All data are displayed in mean \pm standard deviation. Data were evaluated using variance analysis (ANOVA) in SPSS 20.0 followed by Tamhane's Post Hoc test to compare the variations between treatments. Differences of $\mathrm{p}<0,05$ shall be deemed statistically significant.

\section{RESULTS AND DISCUSSIONS}

Qualitatively, the expression of Ki-67 can be shown by measuring the intensity of brown color in each field. The expression Ki-67 is represented by the brown color intensity of the cell cytoplasm. The variation in brown color intensity in the colon epithelial cytoplasm cells can be seen in Figure 1 (a-f). Figure 1(a) has a neutral color intensity. In comparison, Figures 1 (c) and (d) have a high intensity In the meanwhile, Figures 1(b), (e) and (f) have approximately the same intensity of brown colour. The results of this color intenisty are grouped together and statistically analyzed by ImageJ and SPSS.

Quantification of all Ki-67 expression in the images above are assessed by calculating the sum and average of Histo Score (H-score $)^{16}$ for group. The results can be seen as in Table 1. All data from Table 1 have normal distribution based on the Shapiro-Wilk normality test $(p=0.337)$. However, based on the Levene's test the data groups are not homogeneous $(\mathrm{p}<0.001)$. Because the data groups were normally distributed but inhomogeneous, One Way ANOVA statistical analysis was carried out and continued with the post hoc Tamhane Test. ANOVA showed significant results $(\mathrm{p}<0.001)$. Meanwhile, Tamhane's test results showed there were significant differences between positive control and negative control $(\mathrm{p}=0.015)$, PMLEE 200mg and negative control $(\mathrm{p}=$ 0.01 ), PMLEE $300 \mathrm{mg}$ and negative control $(\mathrm{p}=0.001)$, PMLEE $100 \mathrm{mg}$ and PMLEE $300 \mathrm{mg}(\mathrm{p}=0.002)$ as shown in figure 2 .

\section{Ulcerative colitis model with DSS and aspirin}

$\mathrm{UC}$ is a chronic inflammation that occurs in the gastrointestinal tract. In this study, UC was carried out by DSS administration. The effects of DSS administration can mainly be seen in the negative control group. The negative control group also showed a significant difference with the positive control group $(\mathrm{p}=0.015)$. This shows that the administration of DSS and aspirin each succeeded in providing a good model.

The DSS administration can cause chronic inflammation, which is determined by several factors. ${ }^{17}$ Administrative dose is one of the reasons involved. The suggested dosage of DSS is $1.5 \%-3 \%{ }^{17}$ In this study, the authors used a $2 \%$ dose. In addition, length of treatment and frequency of DSS administration are also contributing factors. ${ }^{18}$

\section{Table 1: H-Scores in each group.}

\begin{tabular}{ccccc}
\hline \multirow{2}{*}{ Group } & \multirow{2}{*}{ N } & \multicolumn{2}{c}{ H-Score (\%) } & \multirow{2}{*}{ Cl 95\% } \\
\cline { 3 - 4 } & & Mean & SD & \\
\hline Normal & 5 & 148.50 & 31.39 & $109.5-187.5$ \\
Positive control & 5 & 179.49 & 10.34 & $166.7-192.3$ \\
Negative control & 5 & 213.68 & 11.12 & $199.9-227.5$ \\
PMLEE 100mg & 5 & 186.51 & 3.90 & $181.7-191.4$ \\
PMLEE 200mg & 5 & 176.11 & 10.99 & $162.5-189.8$ \\
PMLEE 300mg & 5 & 156.89 & 6.77 & $148.5-165.3$ \\
\hline
\end{tabular}



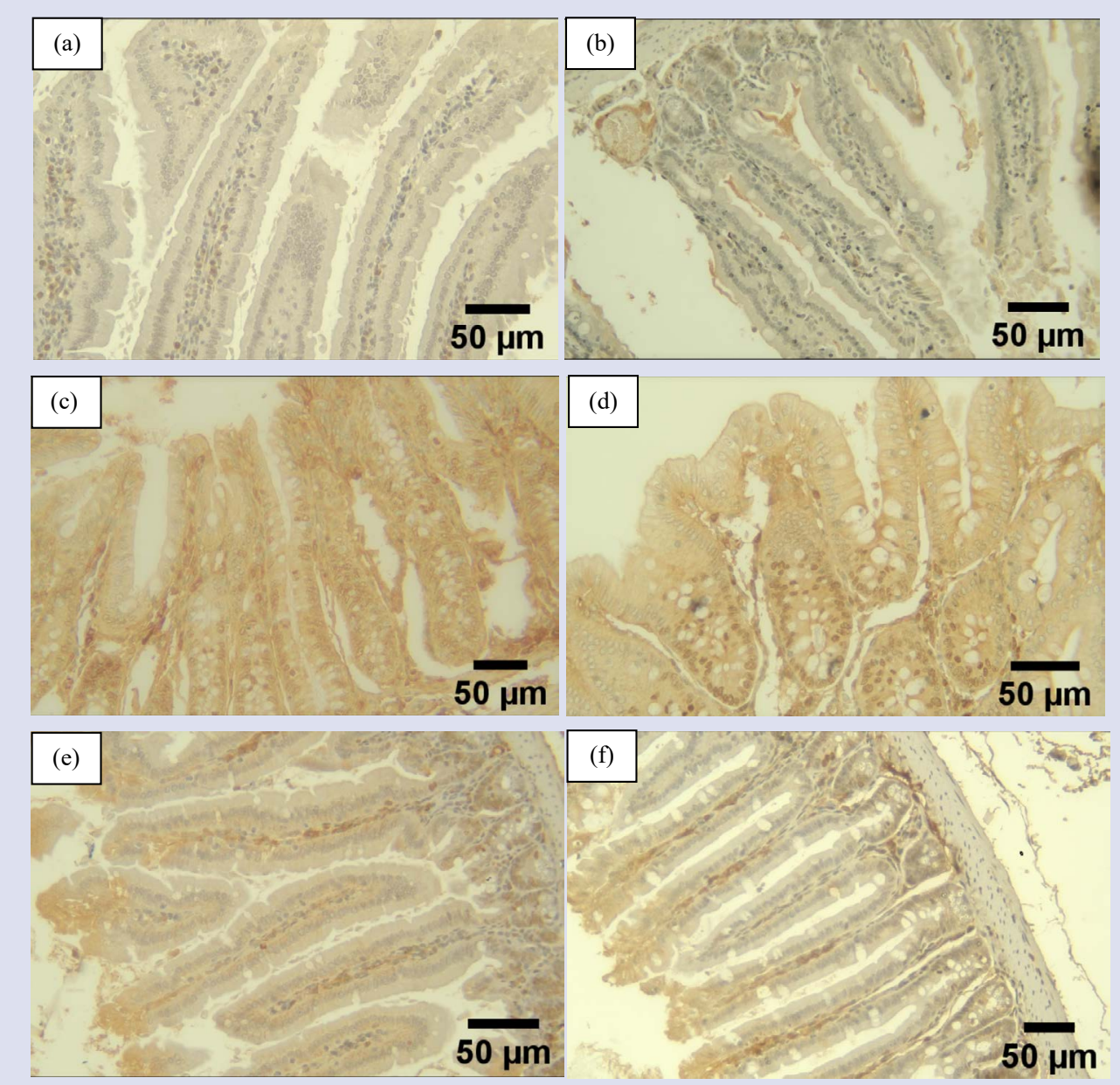

Figure 1: Expression of Ki-67 on Mice Colonic Epithelial Cell with 400X Magnification. (a) normal; (b) positive control; (c) negative control; (d) PMLEE 100 mg; (e) PMLEE 200 mg; (f) PMLEE 300 mg.

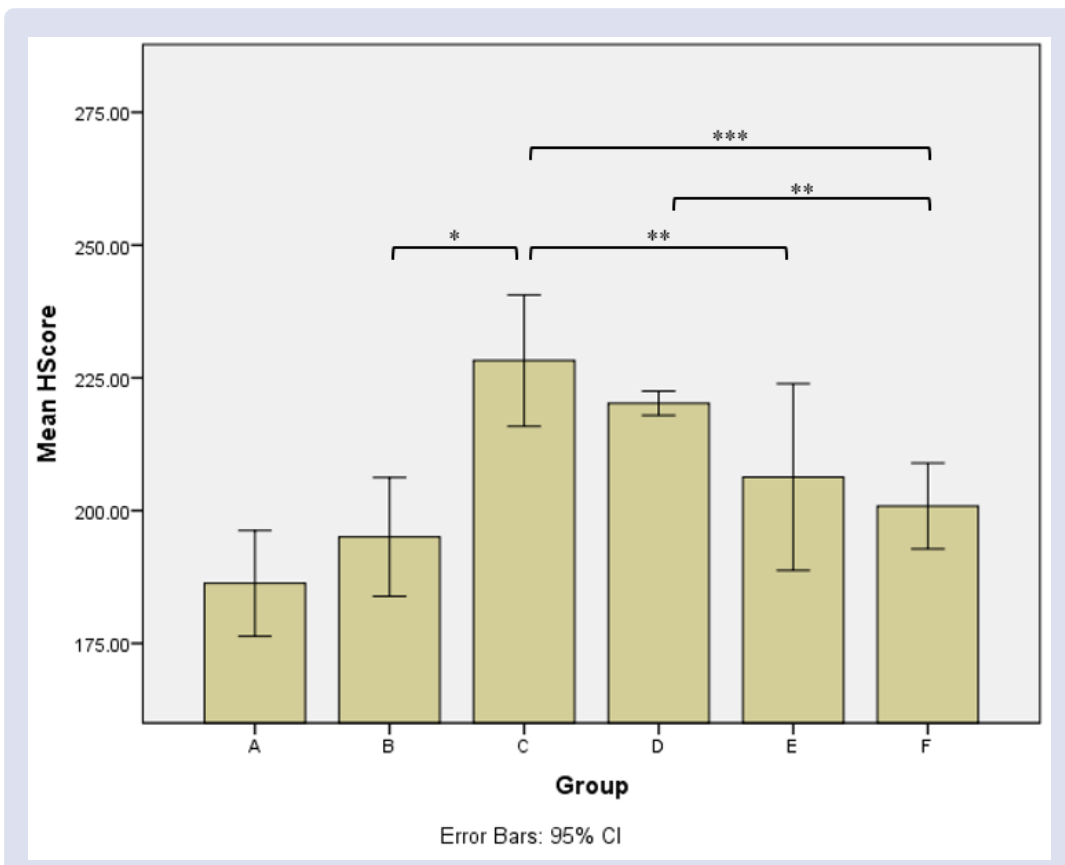

Figure 2: Mean Difference between Groups based on Tamhane's Test. $A=$ normal; $B=$ positive control; $C=$ negative control; $D=P M L E E 100 \mathrm{mg} ; E=P M L E E 200 \mathrm{mg} ; F=P M L E E 300$ mg. ${ }^{*} p<0.05 ;{ }^{* *} p \leq 0.01 ;{ }^{* * *} p \leq 0.001$. 
The prescribed duration and frequency is 5-10 days with 4-5 repeat cycles. ${ }^{17,18}$ The strain of Mice is also one of the factors that affect the efficacy of DSS. In fact, according to research by Mähler et al, C3H/HeJ, $\mathrm{C} 57 \mathrm{BL} / 6$, and $\mathrm{BALB} / \mathrm{c}$ have a strong ulcerative effect. ${ }^{19}$ This is consistent with the research performed by Vetuschi et al, which found that the proliferation index of these strains increased by 40-60 folds relative to normal mice prior to DSS administration. ${ }^{20}$

Aspirin has been known to suppress the mechanism of inflammation. As with Amalia et al, administration of aspirin at a dosage of $150 \mathrm{mg} / \mathrm{kg}$ for 4 weeks decreased the occurrence of dysplasia in the colon tissue. ${ }^{21}$ The same results are also shown in this study. The results showed a significant difference between the negative and positive control groups $(\mathrm{p}=0.015)$. This difference indicates that aspirin given to positive controls has significantly decreased Ki-67 expressions compared with negative controls.

Surprisingly, the normal group did not show significant differences with either positive or negative controls. This can happen for several reasons, mainly because of variability. SD of the normal group reached 31.39 and significant Levene's test results $(\mathrm{p}<0.001)$ showed possible variability due to outlier values. ${ }^{22}$ These outlier values might occur due to several factors, ranging from staining the preparation, image capture, to quantification with the results of Ki-67 expression..$^{23}$ Based on the study of Kim et al, Ki-67 are more vulnerable to ischemia, so over fixation can cause irreversible damage to some epitopes. ${ }^{24}$ In addition, the scanned images of the samples must also be in a good quality. This is where the pathologist needs to do its role to ensure that each scanned photo meets a quality standard that will allow collection of meaningful and reproducible data before being processed by ImageJ. ${ }^{24,25}$ In addition to human error factors, this inhomogeneous data may also be due to system errors. ${ }^{26}$ Therefore, a result of the system sometimes requires validation from a pathologist. ${ }^{26}$

\section{Effect of PMLEE on $\mathrm{KI}-67$ expression}

The effect of PMLEE on the Ki-67 expression showed significant results. This can be seen in the result of Ki-67 expression between negative control and PMLEE 200mg ( $\mathrm{p}=0.01)$ and also between negative control and PMLEE $300 \mathrm{mg}(\mathrm{p}=0.001)$. These results indicate that PMLEE is able to significantly reduce Ki-67 expression. The relationship between PMLEE and Ki-67 is inseparable from the compounds present in PM. The therapeutic effects of this plant have previously been discussed in several studies, especially in terms of anti-inflammatory effects. In fact, the study of Mariani et al states due to its affinity with the ketoprofen receptor, the compound in PM, hydroxyl benzophenone glucoside, has minor anti-inflammatory activity. ${ }^{27}$ However, based on the study of Diantini et al, benzophenone glucoside was not able to significantly reduce the proliferation of human cervical cancer cells. ${ }^{28}$ This suggests that the decrease in the expression of $\mathrm{Ki}-67$, as a proliferation biomarker, may not be related to the activity of benzophenone glucoside. ${ }^{29}$ Besides benzophenone glucoside, it is often considered that other compounds such as flavonoids have anti-inflammatory effects. ${ }^{30}$ In fact, according to the study of Shaikh et al, flavonoids have a high suppression effect on the expression of Ki-67. ${ }^{31}$ One type of flavonoid, epigallocatechin gallate, is known to inhibit Ki-67 in (PRB)-E2F/DP pathway. ${ }^{32}$ The fact that PM in this study comprises flavonoids with levels of $0.3429 \%$ or $3.429 \mathrm{mgQE} / \mathrm{g}$ from the maceration phase further emphasizes this finding. The form of flavonoid found in PM, kaempferol, was thought to be one of the factors that influenced the decrease in Ki-67 expression, according to Kusmardi et al. ${ }^{33}$ This is supported by the study of Qin et al which showed a decrease in the expression of $\mathrm{Ki}-67$ in cholangiocarcinoma cells treated with kaempferol. ${ }^{34}$

Besides showing a relationship with the expression of Ki-67, PMLEE appears to be dose-dependent as well. This can be seen in the significant difference in Ki-67 expression ( $p=0.002)$ between the PMLEE $100 \mathrm{mg}$ and the PMLEE $300 \mathrm{mg}$. In fact, the expression of Ki-67, as seen in Figure 2, is inversely proportional to the dose of PMLEE. This can occur in one of them due to the activity of the compound phalerin and gallic acid in PM, according to the Altaf et al report. ${ }^{35}$ In a dose-dependent manner, the compound is thought to increase the development of BAX protein while down-regulating the Bcl-2 mRNA expression. ${ }^{35}$

\section{CONCLUSSION}

PM is a medicinal plant which has been extensively studied as having anti-inflammatory effects. This effect was also related to the expression of Ki-67 in cells as in this study it was inversely proportional. The relationship between PM and Ki-67 still needs to be investigated. In addition, the dose of $\mathrm{PM}$ is also a determining factor for $\mathrm{Ki}-67$ expression. The dose dependent characteristics of this plant on Ki-67 expression also need further research. Research related to the use of other inflammatory markers on UC, beside $\mathrm{Ki}-67$, need to be done in order to understand anti-inflammatory properties of PM.

\section{ACKNOWLEDGEMENT}

We would like to thank Directorate of Research \& Development Universitas Indonesia and also Ministry of Research / National Agency for Research and Innovation for the funds provided.

\section{REFERENCES}

1. Sharara Al, Awadhi SA, Alharbi O, Dhahab HA, Mounir M, Salese $\mathrm{L}$, et al. Epidemiology, disease burden, and treatment challenges of ulcerative colitis in Africa and the Middle East. Expert Rev Gastroenterol Hepatol. 2018 Sep; 12(9): 883-97.

2. Ng SC, Shi HY, Hamidi N, Underwood FE, Tang W, Benchimol El, et al. Worldwide incidence and prevalence of inflammatory bowel disease in the 21 st century: a systematic review of population-based studies. Lancet. 2018 Dec 23; 390(10114): 2769-78.

3. Pratama N, Abdullah M, Kansera DD, Estherina J, Yaruntradhani R, Hardi F, et al. Prevalence of crohn s disease in endoscopic unit Cipto Mangunkusumo hospital. Indonesian Journal of Gastroenterology. 2011; 12 (2): 85-8.

4. da Silva BC, Lyra AC, Rocha R, and Santana GO. Epidemiology, demographic characteristics and prognostic predictors of ulcerative colitis. World J Gastroenterol. 2014 Jul 28; 20(28): 9458-67.

5. Lawton J, Achit H, Pouillon L, Boschetti E, Demore B, Matton T, et al Cost-of-illness of inflammatory bowel disease patients treated with anti-tumour necrosis factor: A French large single-centre experience. United European Gastroenterol J. 2019 Aug;7(7): 908-13.

6. Le Berre C, Ananthakrishnan AN, Danese S, Singh S, and PeyrinBiroulet $L$. Ulcerative colitis and crohn's disease have similar burden and goals for treatment. Clin Gastroenterol Hepatol. 2020 Jan;18(1):14-23.

7. Simadibrata M, Halimkesuma CC, and Suwita BM. Efficacy of curcumin as adjuvant therapy to induce or maintain remission in ulcerative colitis patients: An evidence-based clinical review. Acta Medica Indonesiana. 2017; 49 (4): 363-8.

8. Welz AN, Emberger-Klein A, and Menrad K. Why people use herbal medicine: insights from a focus-group study in Germany. BMC Complement Altern Med. 2018 Mar 15; 18(1):92

9. Zhang J, Onakpoya IJ, Posadzki P, and Eddouks M. The safety of herbal medicine: From prejudice to evidence. Evid Based Complement Alternat Med. 2015; 2015: 316706.

10. Mahzir KAM, Gani SSA, Zaidan UH, and Halmi MIE. Development of phaleria macrocarpa (scheff.) boerl fruits using response surface methodology focused on phenolics, flavonoids and antioxidant properties. Molecules. 2018 Mar 22; 23(4): 724.

11. Woldemeskel M, Hawkins I, and Whittington L. Ki-67 protein expression and tumor associated inflammatory cells (macrophages and mast cells) in canine colorectal carcinoma. BMC Vet Res. 2017 Apr 20; 13(1): 111. 
12. Pessler F, Ogdie A, Diaz-Torne C, Dai L, Yu X, Einhorn E, et al. Subintimal Ki-67 as a synovial tissue biomarker for inflammatory arthropathies. Ann Rheum Dis. 2008 Feb; 67(2): 162-7.

13. Maharani R, Kusmardi K, and Elya B. Inhibitory activity goblet depletion and focal inflammatory Phaleria macrocarpha leaves ethanol extract on crypta mouse after dextran sodium sulphate induction. Int J PharmTech Res. 2019; 12(1): 37-48.

14. Kusmardi K, Fitriyasa RD. Anti-inflammatory effect of Tabat Barito (Ficus deltoidea) leaf extract on small intestine mice-induced by dextran sodium sulfate. Int J Pharm Res | Jan - March 2020, Vol 12 , Issue 1.

15. Kusmardi K, Wiyarta E, Estuningtyas A, Sahar N, Midoen YH, Tedjo A. Potential of Phaleria macrocarpa Leaves Ethanol Extract to Upregulate the Expression of Caspase-3 in Mouse Distal Colon after Dextran Sodium Sulphate Induction. Pharmacognosy Journal. $2021 ; 13(1): 23-29$.

16. Fardet L, Galicier L, Lambotte O, Marzac C, Aumont C, Chahwan $D$, et al. Development and validation of the HScore, a score for the diagnosis of reactive hemophagocytic syndrome. Arthritis Rheumatol. 2014 Sep; 66(9): 2613-20.

17. Eichele DD and Kharbanda KK. Dextran sodium sulfate colitis murine model: An indispensable tool for advancing our understanding of inflammatory bowel diseases pathogenesis. World J Gastroenterol. 2017 Sep 7; 23(33): 6016-29.

18. Biton IE, Stettner N, Brener O, Erez A, Harmelin A, and Garbow JR. Assessing mucosal inflammation in a dss-induced colitis mouse model by mr colonography. Tomography. 2018 Mar; 4(1): 4-13.

19. Mähler M, Bristol IJ, Leiter EH, Workman AE, Birkenmeier EH, Elson $\mathrm{CO}$, et al. Differential susceptibility of inbred mouse strains to dextran sulfate sodium-induced colitis. Am J Physiol. 1998 Mar; 274(3): G54451.

20. Vetuschi A, Latella G, Sferra R, Caprilli R, and Gaudio E. Increased proliferation and apoptosis of colonic epithelial cells in dextran sulfate sodium-induced colitis in rats. Dig Dis Sci. 2002 Jul; 47(7): 1447-57.

21. Amalia AW, Kusmardi, Elya $B$, Arsianti A. Inhibition of carcinogenesis by seed and soybean meal extract in colon of mice: Apoptosis and dysplasia. Asian J Pharm Clin Res. 2017 Apr 1; 10(4): 123.

22. Kwak SK and Kim JH. Statistical data preparation: management of missing values and outliers. Korean J Anesthesiol. 2017 Aug; 70(4): 407-11.

23. Karki S. Errors : Detection and minimization in histopathology laboratories. Journal of Pathology of Nepal. 2015; 5: 859-64
24. Kim SW, Roh J, and Park CS. Immunohistochemistry for pathologists: protocols, pitfalls, and tips. J Pathol Transl Med. 2016 Nov; 50(6): 411-8.

25. Aeffner F, Zarella MD, Buchbinder N, Bui MM, Goodman MR, Hartman DJ, et al. Introduction to digital image analysis in whole-slide imaging: a white paper from the digital pathology association. J Pathol Inform. 2019; 10 : 9.

26. Mane DR, Kale AD, and Belaldavar C. Validation of immunoexpression of tenascin-C in oral precancerous and cancerous tissues using ImageJ analysis with novel immunohistochemistry profiler plugin: An immunohistochemical quantitative analysis. J Oral Maxillofac Pathol. 2017 May-Aug; 21(2): 211-7.

27. Mariani R, Wirasutisna KR, Nawawi A, and Adnyana IK. Antiinflammatory activity of dominant compound of mahkota dewa fruit Phaleria macrocarpa Scheff. Boerl. Majalah Farmasi Indonesia. 2010; 21(2): 129-33.

28. Diantini A, Subarnas A, Achmad TH, Supriyatna, Kurnia D, Faried A, et al. Activity of benzophenone glucoside from mahkota dewa \{phaleria macrocarpa (scheff.) boerl.\} fruits on proliferation of human cervicalcancer cells (hela and caski) and human esophageal cancer cells (te2, te-8, and te-14). Bionatura. 2018 Jul 1; 10 (2): 97-103.

29. Sun $X$ and Kaufman PD. Ki-67: more than a proliferation marker Chromosoma. 2018 Jun; 127(2): 175-86.

30. Hendra R, Ahmad S, Oskoueian E, Sukari A, and Shukor MY Antioxidant, anti-inflammatory and cytotoxicity of phaleria macrocarpa (boerl.) scheff fruit. BMC Complement Altern Med. 2011; 11: 110.

31. Shaikh SB, Prabhu A, and Bhandary YP. Curcumin suppresses epithelial growth factor receptor (egfr) and proliferative protein ( $\mathrm{ki}$ $67)$ in acute lung injury and lung fibrosis in vitro and in vivo. Endocr Metab Immune Disord Drug Targets. 2019 Aug 23; 11 (1): 28.

32. Abotaleb M, Samuel SM, Varghese E, Varghese S, Kubatka P, Liskova A, et al. Flavonoids in cancer and apoptosis. Cancers (Basel). 2019 Jan; 11(1): 28

33. Kusmardi K, Estuningtyas A, Shavera D, Tedjo A, and Priosoeryanto BP. The effect of mahkota dewa (phaleria macrocarpa) (scheff.) fruit pericarp extract on inos in mice colon intermittently-induced by dextran sodium sulfate. Asian Journal of Pharmaceutical and Clinical Research. 2017 Dec; 10 (12): 309-12.

34. Qin Y, Cui W, Yang X, and Tong B. Kaempferol inhibits the growth and metastasis of cholangiocarcinoma in vitro and in vivo. Acta Biochim Biophys Sin (Shanghai). 2016 Mar;48(3): 238-45.

35. Altaf R, Asmawi MZB, Dewa A, Sadikun A, and Umar MI. Phytochemistry and medicinal properties of phaleria macrocarpa (scheff.) boerl. extracts. Pharmacogn Rev. 2013 Jan-Jun; 7(13): 73-80. 


\section{GRAPHICAL ABSTRACT}
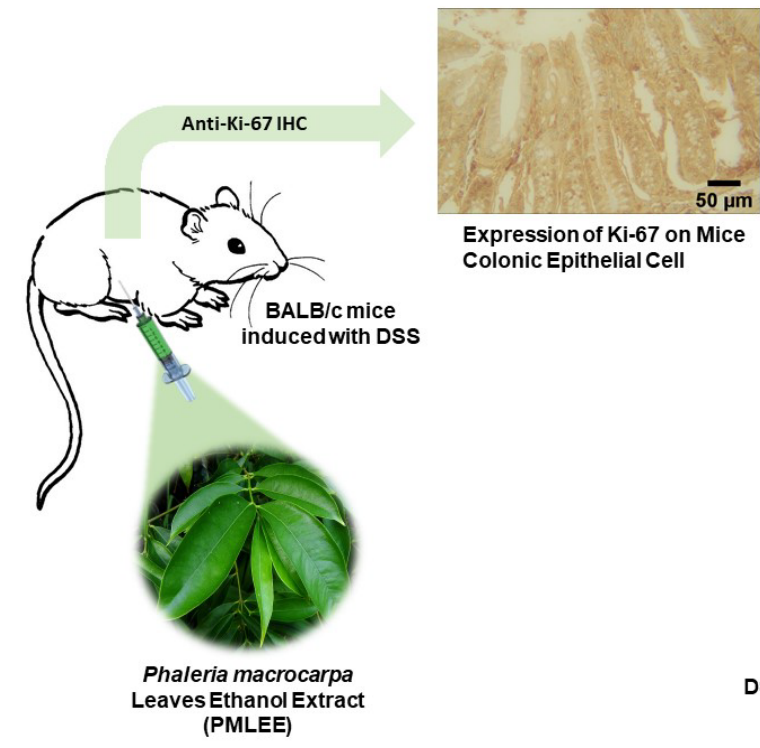

Expression of $\mathrm{Ki}-67$ on Mice Colonic Epithelial Cell
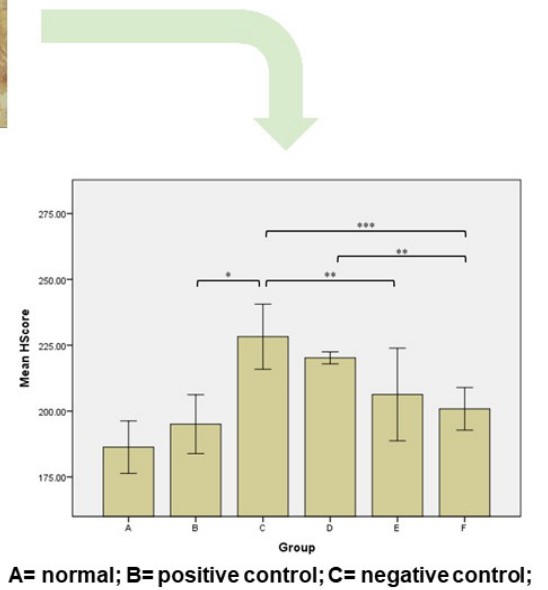
D= PMLEE 100mg; E= PMLEE 200mg; F= PMLEE $300 \mathrm{mg}$

\section{ABOUT AUTHORS}

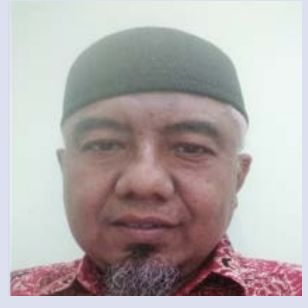

Kusmardi (M.Sc. PhD): Lecturer and Researcher at Pathological Anatomy and Drug Development Research Center Indonesian Medical Education and Research Institute, Faculty of Medicine, Universitas Indonesia. Research interest in Immunology, Pathology, Cancer Biology, Herbal Medicine, Biomedical Sciences, Oncology, Animal Model for Cancer Research, Biostatistic, and Research Methodology.

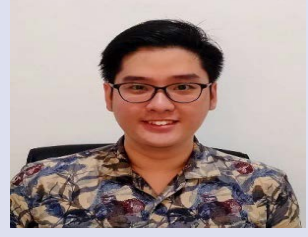

Elvan Wiyarta: Medical student and Researcher at Pathology Anatomy Department, Faculty of Medicine, Universitas Indonesia. Research interest in Immunology, Pathology, Herbal Medicine, Bioinformatics, and Neuroscience.

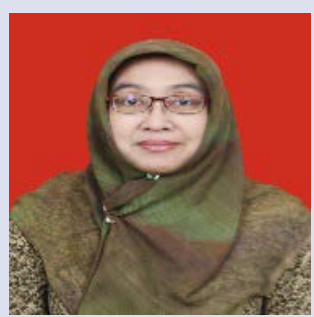

Ari Estuningtyas (M.Sc., Ph.D): Lecturer and Researcher at Pharmacology \& Therapeutics, Faculty of Medicine, Universitas Indonesia. Research interest in Pharmacology, Drug Discovery \& Drug Development, Animal Models in Drug Development, Herbal Medicine, Biomedical Sciences.

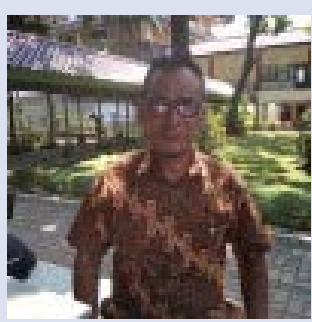

Nurhuda Sahar (M.Sc.,Ph.D): Lecturer and Reseacher at Biology Reproductive, Faculty of Medicine,

University Indonesia. Research Interest in Reproductive Endocrinoogy, Assisted Reproductive and Animal model for human Reproductive research. 


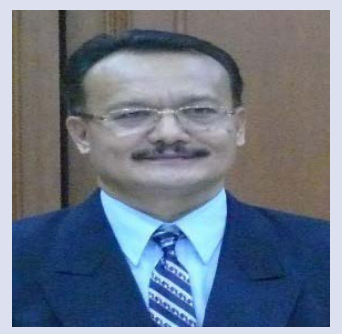

Yurnadi (M.Sc., Ph.D): Lecturer and Researcher at Department of Medical Biology, Faculty of Medicine Universitas Indonesia. Research interest in Molecular Biology, Andrology, Human Genetic, and Cancer Biology.

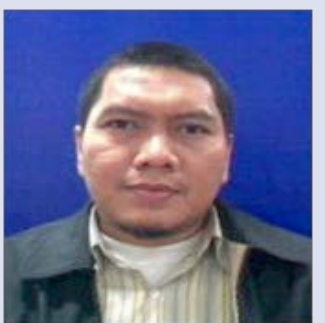

Aryo Tedjo (S.Sc., M.Sc): Lecturer and Researcher at Medical Chemistry and Drug Development Research Center Indonesian Medical Education and Research Institute, Faculty of Medicine, Universitas Indonesia. Research interest in Analytical Chemistry and Herbal Medicine.

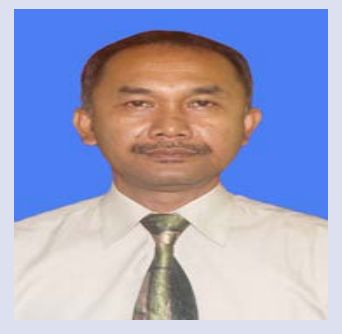

\section{Alfred Pakpahan (M.Sc)}

Lecturer and Researcher at Faculty of Dentistry and Faculty of Medicine Universitas Trisakti. Research interest in Natural product medicine, Bioinformatics, Genetic, Immunobiology, Developmental Biology and Radiobiology.

Cite this article: Kusmardi K, Wiyarta E, Estuningtyas A, Sahar N, Midoen YH, Tedjo A, et al. Potential Inhibition by Phaleria macrocarpa Leaves Ethanol Extract on Ki-67 Expression in Distal Colon Mouse. Pharmacog J. 2021;13(2): 443-9. 